\title{
Legal Description of Witnesses in the Criminal Investigation via Teleconference New Normal Era
}

\author{
Putu Aditya Darma Putra \\ \{aditya.darma@undiksha.ac.id\} \\ Universitas Pendidikan Ganesha, Indonesia
}

\begin{abstract}
During the Covid-19 pandemic, the health protocol is an indispensable procedure to stop the spread of the Covid-19 virus in Indonesia. One of the government's efforts to stop the spread of this virus is to carry out online activities, including investigations at judicial institutions as well as by teleconference. The type of research used by researchers in this study is a type of normative legal research, this study examines the testimony of witnesses in the Criminal Code and Law Number 13 of 2006 concerning Witness and Victim Protection. Normative research draws data from literature and examines relevant laws, jurisprudence and doctrine. This article discusses the strength of proof of witnesses being examined by teleconference in criminal case examination. the examination of witnesses by teleconference in order to have the power of proof must meet the requirements, including presenting detailed images and clear sound quality without interference (noise), enabling judges to know directly the eyes, facial features, and body language (gestures) shown by a witness before the trial.
\end{abstract}

Keywords: Teleconference; Witnesses; and Legal Arrangements

\section{Introduction}

On March 11, 2020, the world health organization World Health Organization or abbreviated WHO has announced the 2019 Corona Virus Disease to be an International Pandemic called Coronavirus Pandemic. This means that countries around the world must respond to, prevent and deal with this corona virus pandemic. Indonesia is one of the countries affected by this pandemic which has made preventive efforts to break the chain of spreading the Covid-19 virus.

Large-Scale Social Restrictions are a solution implemented by the Indonesian government which is regulated in the Minister of Health Regulation Number 9 of 2020 concerning Guidelines for Large-Scale Social Restrictions in the Context of Accelerating the Management of Corona Virus Disease 2019 (COVID-19). The government advised the Indonesian people to carry out work or study activities at home online, as well as activities in government. It was recorded that until September 21, 2020 there were 248,852 confirmed cases and 9,677 people were declared dead[1].

And since last August the government issued a new normal scenario, where in this scenario people who are in the moderate level of the Covid-19 spread zone can continue their activities by paying attention to health protocols. However, the government still urges the public to carry out activities online or online to prevent crowds in one place. 
In this new normal era, the judiciary also plays an active role in breaking the chain of the spread of COVID-19 in Indonesia, the Supreme Court of the Republic of Indonesia, the Attorney General's Office, and the Ministry of Law and Human Rights have also entered into a Cooperation Agreement Number 402 / DJU / HM.01.1 / 4 / 2020, Number KEP-17 / E / EJP / 04/2020, Number PAS-08.HH.05.05 of 2020 concerning the implementation of trials via teleconference, in criminal case examination in the new normal era, an online examination system has also been carried out. By teleconference. However, the examination of criminal cases carried out by teleconference still invites long debate and pros and cons in the community, because there is no related article regulating teleconferencing in the Criminal Code[2].

Moreover, in the examination of witnesses by teleconference, it is still a matter of debate in its implementation at court. Evidence has a very important position in the examination process at trial because it is through this evidence that the fate of the defendant is determined and only by proving a criminal act can a criminal be imposed. In essence, evidence is part of the criminal procedure law which regulates various types of evidence which are valid according to law, the system adopted in the evidence, the requirements and procedures for presenting the evidence and the judge's authority to accept, reject and evaluate evidence. Witness testimony plays a very important role in uncovering facts in court about the criminal act that occurred, but witnesses must meet the requirements as a person who knows, hears, and has experienced a criminal act himself, not a witness who obtains a statement. From hearing. Other (testimonium de auditu). The witness testimony at the trial will have the power of proof if the witness is appointed[3];[2]

The proof system that applies in criminal procedural law is the system of proof before the court which is regulated in article 185 of the Criminal Procedure Code, which states that "witness testimony as evidence is what the witness said at trial".[4]

Witness testimony is the main means of evidence in proving a criminal case, however not all witness testimonies can become valid evidence, this of course must meet the requirements so that the witness can become evidence, including:

a. The witness must take an oath or promise that he or she is will explain the truth and nothing is true anymore;

b. The information provided must be about a criminal event that the witness heard, witnessed, or experienced, clearly stating the source of his knowledge. Witness statements in the form of repeated stories from other people have no information value as evidence. Likewise, the opinion or fiction that the witness gets from the results of his thoughts cannot be considered as valuable information as evidence;

c. Witness testimony must be declared in court. Statements outside court proceedings have no value as valid evidence;

d. The testimony of a witness alone is not valid evidence, therefore the minimum limit of proof stipulated in Article 183 of the Criminal Code must be fulfilled.

Before imposing a sentence, a judge must observe 2 (two) absolute conditions stipulated in the Criminal Procedure Code, namely: sufficient and valid evidence and conviction of the judge. Legal evidence in criminal procedural law is regulated in the provisions of Article 184 paragraph (1) of the Criminal Procedure Code, among others: witness statements, expert statements, letters, instructions and statements of defendants[2]

Whereas in the world of justice in Indonesia, the use of teleconferencing has been widely used, namely in 2002 the Supreme Court granted permission to the former President BJ for the first time. Habibie gave testimony via teleconference in the case of irregularities in Bulog's non- 
budget funds on behalf of the defendant Rahardi Ramelan. Then the case of gross human rights violations in East Timor was submitted to the Central Jakarta District Court on the grounds of security and time efficiency. So that the teleconference statement was held in the city of Dili, while the defendant was at the Central Jakarta District Court. Likewise with the trial of Abu Bakar Ba'asyir, the defendant in the plot to bomb several churches on Christmas Eve 2000 and the plot to assassinate Megawati, who was still Vice President at that time. In addition, in Bali, the witness was questioned by teleconference at the Denpasar District Court in the Bali Bombing terrorism case where the defendant was Ali Gufron alias Muklas alias Sofwan who presented witness Wan Min bin Wan Mat who was in Malaysia. And finally in 2011, the examination by teleconference was again carried out in the case of Abu Bakar Ba'asyir, with 16 (sixteen) witnesses who will provide information.

This article will discuss the strength of proof of witnesses being examined by teleconference in criminal case examination.

\section{Method}

This type of research used by researchers in this study is a type of normative legal research. Normative legal research is research conducted by reviewing the laws and regulations that apply or are applied to a particular legal issue. Normative research is often referred to as doctrinal research, namely research whose object of study is documents of laws and regulations and library materials.

This research examines the testimony of witnesses in the Criminal Code and Law Number 13 of 2006 concerning Witness and Victim Protection. Normative research draws data from literature and examines relevant laws, jurisprudence and doctrine.

\section{Results And Discussion}

Tool As explained by the author above, although trial examinations have been carried out several times by teleconference, in fact the arrangements for trial examination via teleconference have not been regulated by law.

In the Criminal Procedure Code there are no legal rules governing teleconferencing, but only under the guise of laws regulating the development of evidence in a lex specialist manner, while explicit provisions regarding teleconferencing are contained in jurisprudence[5].

However, in the law system civil, jurisprudence is persuasive in nature "so that there is no obligation for judges in Indonesia to use teleconferencing and it is also not an obligation under the applicable criminal procedural law in Indonesia to use teleconferencing in the supervisory process"[4]

And in connection with this pandemic, which has entered a new normal era, the Supreme Court of the Republic of Indonesia, the Attorney General's Office, and the Ministry of Law and Human Rights have also entered into a cooperation agreement Number 402 / DJU / HM.01.1 / 4/2020, Number KEP- 17 / E / EJP / 04/2020, Number PAS-08.HH.05.05 of 2020 concerning the implementation of the trial by teleconference.

In connection with the use of the teleconference, provisions that can be used as a basis for measuring the strength and facts, among others, by observing and reviewing the provisions contained in Article 183 to Article 189 of the Criminal Code in conjunction with Article 3 of the Indonesian Code of Law. Criminal Procedure Law; Article 284 paragraph (2) of the Criminal 
Procedure Code and Article 10 paragraph (1) and Article 5 paragraph (1) of Law Number 48 of 2009 concerning Judicial Powers[6]

Information conveyed in front of court proceedings that have expanded the meaning in accordance with the development of society in the fields of technology and law. Examinations Teleconference have been regulated in statutory regulations as a form of anticipation for legal developments in the information technology sector, because the Criminal Code has not been regulated. The witness's testimony has developed, along with the development of public knowledge in the field of technology and information today. In criminal justice practice, information is no longer given directly (physically) and must be tried to give testimony.

Currently, the Indonesian world court has introduced a remote examination method using multimedia or technology teleconferencing. One of the laws and regulations that help prove by teleconference is Article 9 of Law Number 13 of 2006 concerning Protection of Witnesses and Victims.

If the examination of the Criminal Code that is examined by teleconference is in fact contrary to Article 160 paragraph (1) and Article 167 paragraph (1) of the Criminal Code. Article 160 paragraph (1) letter a of the Criminal Code states "witnesses are summoned to the courtroom one by one according to the order which is fine by the head of the trial after hearing the opinion of the public prosecutor, the accused or the defendant's legal advisor". Then Article 167 paragraph (1) of the Criminal Code stipulates, "After the letter provides a statement, he will still be present at the trial unless the chairman of the trial gives permission to leave him". Based on these provisions, the presence of a physical witness is required to attend and testify at trial.

Likewise, Article 185 paragraph (1) of the Criminal Code states that "a certificate is a means of evidence to state what is stated in court". So that the words mentioned in front of the trial here are not clear (absurd), because the Criminal Code itself does not explain or in giving testimony in front of the trial the witness must be present (physically) to the court to give testimony. Under the law, the sentence which states "written statement before the trial" that reveals the loophole for examining, examining is explicitly contained in the provisions of Article 9 of Law no. 13 of 2006 concerning Protection of Witnesses and Victims, of which there are three choices of witnesses who do not have to be presented to court, namely:[4]

a. Witnesses are permitted to give written statements in front of officials such as notaries, judges, or district heads;

b. Information can be retrieved by teleconference;

c. The examination is like a mystery guest, who provides information in a special room.

In fact, according to the author of the document through teleconference, in fact, it has fulfilled Article 185 paragraph (1) of the Criminal Code which in essence is stated as "witness evidence as evidence that the witness declares at court", where the teleconference statement is also stated in before the trial, but not directly (physically) present at the trial. From this provision, textually it is not required to have a physical witness in the room, but in Article 160 paragraph (1) letter a and Article 167 of the Criminal Code, which stipulates that the physicality of an officer is absolute. However, in reality, to seek and enforce the truth which leads to textual justice, in practice it will be responded.

In Article 10 paragraph (1) of Law Number 48 of 2009 concerning Judicial Powers, then the situation is that the judge has the obligation to examine and issue a decision, which means he is obliged to find the law. Based on the idea that in a society that is still familiar with unwritten law and the existence of upheavals and transitions, the judge is a formulator and 
digger of values that live among people, for that he must go into society to know, feel and be able to understand the feelings of law and living justice. In society. Thus the judge can give a decision in accordance with the law and public justice, this is in accordance with Article 5 paragraph (1) of Law Number 48 of 2009 concerning Judicial Power.[7]

The provisions of Article 5 paragraph (1) of Law no. 48 of 2009 concerning Judicial Power, judges as law enforcers and justice must be tried, follow and understand the legal values of a sense of justice that live in society. So that in pursuing, understanding, and pursuing material truth in criminal law. In criminal law where a person can be accused of having committed a certain criminal act, based on evidence submitted with the conviction of the judge who stated it, when in fact he is not responsible, so that a judge's decision based on the evidence can lead to a person who is free without retribution, whereas the same irresponsible person became convicted in a very unfair way. Therefore, the method of proof developed by the judge must really be justified, so that it can actually produce justice.

So, it is an important task for judges to regulate adjusting laws with real issues in society. If a law cannot be implemented according to the meaning it says, the judge is obliged to interpret it so that he can make decisions that are fair and in accordance with the purpose of law, namely to achieve legal certainty.[8]

The development of the law is quite wise in regulating legislation. For example, teleconferencing, which is not regulated in the Criminal Procedure Code, cannot be conducted. In fact, in fact, the estuary of law enforcement should ideally be relatively focused on the correctness of the material that must be sought so that administrative, formal and relatively less substantial aspects are followed up. However, in the Criminal Procedure Code itself, there are no provisions prohibiting the use of teleconferencing itself.

Therefore, an active role of judges is needed in accordance with Article 5 paragraph (1) of Law Number 48 of 2009 concerning Judicial Power, in order to make new legal discoveries (rechtfinding) to achieve material truth and justice in accordance with the expectations of society. Therefore, the authors agree with the use or use of teleconferencing in trial examinations for law enforcement provided that it does not conflict with norms and public order prevailing in society.

The pros and cons of examining by teleconference in court actually depend on whether it is detrimental or beneficial to each party. Teleconferencing is only one form of technological means to hear information only. However, the injured party is of the opinion that the examination of witnesses at trial via teleconference / video conference is not regulated in the Criminal Code, so it is unacceptable and may violate the Criminal Code[2]

Regarding the power of proof of reports through teleconference, this is clearly still related to the previous discussion. Whereas in order to assess the correctness of the proof of the witnesses provided by teleconference, it must first be clear that the identity is valued as valid evidence as regulated in Article 184 paragraph (1) of the Criminal Code.

Thus the main thing that plays a role in the process of investigating criminal cases is legal evidence as regulated in Article 184 of the Criminal Code.

It should be noted that since the inception of the Criminal Code to the use of electronic media, especially teleconferences in criminal proceedings, it shows that there are several innovative things in the perspective of procedural law, especially the proof system where the development of information technology and telecommunications today has also colored 
development of the world of law and justice itself. As for the weaknesses of the Criminal Code, it is necessary to immediately overcome and find a solution.

Court proceedings by teleconference are not regulated in the Criminal Code, so that their legality issue is highly interpretive. However, the use of teleconferencing as evidence in court, from various ideas of thought, has begun to converge that teleconference is the closest correlation to evidence.

The proof system in Indonesia is a combination of a conviction-in time (vrijbewijk) system and a positive proof system (positief wettelijk stelsel). Thus, the judge's conviction is an important thing in the proof system. As a belief, it is convictive and subjective, so it is difficult to test objectively. To get conviction, the judge must be able to physically understand the person's background, behavior and body language in court face to face.[3]

As regulated in the Criminal Code, there are several provisions regarding legal provisions so that they can be used as evidence. What is meant by testimony according to M. Karjadi and $\mathrm{R}$. Soesilo is "a statement orally before the Judge with an oath regarding matters concerning certain events that have been heard, seen and seen by themselves". If the provisions concerning the above are applied in the testimony given by teleconference during the trial using the teleconference media for the examination, it can be said as follows:

a. Witness testimony before the court session. The use of teleconferencing in this case has displayed detailed images and sound quality that is not clearly disturbed (noise), supporting judges to directly see the eyes, facial features, or body language (gestures) shown by a witness in front of the trial. Thus, in principle, the physical presence of a witness before the trial as referred to is fulfilled by means of teleconferencing.

b. With an oath in advance. In accordance with the provisions of Article 160 (3) of the Criminal Code, in utilizing teleconferencing technology it is not much different from an ordinary trial, namely before giving a compulsory testament or promise according to one's respective religious methods, that he is giving true information and nothing else. From the real thing.

c. About certain events that he heard, he saw and experienced himself (Nontestimonium de Auditu). As is the case in every criminal trial, that the witness testimony is one evidence of a criminal case in the form of information from a criminal event which he has heard himself, he has seen and experienced himself by mentioning the reasons for his knowledge. In this case, the teleconference will be valid evidence as long as it does not deny it.[9]

If the legal requirements of the letter have been fulfilled, then the letter has been given by a witness who has the power of proof that can state it as evidence. The witness's testimony will be used as a consideration for a judge to give a verdict on a criminal act. Thus, the legality of testimony via teleconference becomes clearer.

In order for a legal umbrella regarding witness examination by means of carried out teleconference before it's against the Criminal Code, it is necessary Supreme Court to issue new or instructions for its implementation. Policy this can be in the form of Supreme Court regulations regarding the procedure or the latest regarding news examination by teleconference. This is important to do by not giving comments on the pros and cons in practice, because in practice this has already been carried out in court[10].

The use of teleconferencing in the examination of witnesses in a case that contradicts the theory of proof according to the law negatively by the Criminal Procedure Code, where in determining whether or not a defendant must be with at least 2 (two) valid evidence according 
to the law as well as the judge's conviction that the criminal act actually occurred and the accused was the perpetrator. Because the use of teleconferencing in the examination of criminal cases for the author is as a means of obtaining the truth of a criminal act.

The use of teleconferencing in the examination of criminal cases in court according to the author is a breakthrough in the field of law as a form of human activity developed by Information and Communication Technology. Making the human problem the main problem of the writer in Satjipto Rahardjo's thought with his progressive law that places humans as the starting point. According to him, legal thinking needs to return to the philosophy of reality, namely law for humans, not the other way around.

\section{Conclusion}

Prove a certificate by means of a valid teleconference as evidence in the criminal court process, then the conditions that must be fulfilled are the testimony of witnesses before a court session, with an oath in advance and regarding certain events that he has heard, seen and experienced himself (Nontestimonium de Auditu). If the provisions regarding witnesses above are applied in the testimony given by teleconference in a trial that utilizes the teleconference media for which the examination is carried out, then first, the witness's statement before the court session. The use of teleconferencing in this case has displayed detailed images and sound quality that is not clearly disturbed (noise), supporting judges to directly see the eyes, facial features, or body language (gestures) shown by a witness in front of the trial. Thus, in principle, the physical presence of a witness before the trial as referred to is fulfilled by means of teleconferencing.

\section{References}

[1] BPKP, “Total Dana Penanganan Corona Rp. 800 T di 2020,” CNN Indonesia, 2020.

[2] K. Holtfreter, "Is occupational fraud 'typical' white-collar crime? A comparison of individual and organizational characteristics," J. Crim. Justice, vol. 33, no. 4, pp. 353$365,2005$.

[3] E. R. Quinney, "The Study of White Collar Crime: Toward A Reorientation in Theroy and Research," J. Crim. L. Criminol. Police Sci, vol. 55, p. 208, 1964.

[4] D. O. Friedrichs, "Occupational crime, occupational deviance, and workplace crime: Sorting out the difference," Crim. Justice, vol. 2, no. 3, pp. 243-256, 2002.

[5] J. Bertrand, "Indonesia's quasi-federalist approach: Accommodation amid strong integrationist tendencies," Int. J. Const. Law, vol. 5, no. 4, pp. 576-605, 2007.

[6] T. Pavone, "Political Culture and Democratic Homeostasis: A Critical Review of Gabriel Almond and Sidney Verba' s The Civic Culture Tommaso Pavone ( tpavone@princeton.edu ), April 7 th , 2014 Synopsis Background on Structural Functionalism Almond and Verba ( 1963 ),”vol. 37, no. 3, pp. 1-5, 2014.

[7] C. L. Jurkiewicz and R. G. Brown, "Power Does Not Corrupt Absolutely: An Empirical Study," Public Integr., vol. 2, no. 3, pp. 195-210, 2000.

[8] H. M. Bungin, Penelitian Kualitatif: Komunikasi, Ekonomi, Kebijakan Publik, dan Ilmu Sosial Lainnya. Jakarta: Kencana Prenada Media Group, 2009.

[9] B. I. Warongan, “Organizational culture on bsa owner motorcycle 'siantar (bom's) in 
pematangsiantar city Budaya Organisasi Pada BSA Owner Motorcycle' Siantar (BOM’S) Di Kota Pematangsiantar," J. Ilm. Kaji. Polit. Lokal dan Pembang., pp. 187194, 2014.

[10] A. K. Pandey, “The Truth About Article 370.," J. Const. Law Jurisprud., pp. 40-42, 2019. 